Ruzekova, V., Kittova, Z., \& Steinhauser, D. (2020). Export Performance as a Measurement of

Competitiveness. Journal of Competitiveness, 12(1), 145-160. https://doi.org/10.7441/joc.2020.01.09

\title{
EXPORT PERFORMANCE AS A MEASUREMENT OF COMPETITIVENESS
}

\section{- Viera Ruzekova, Zuzana Kittova, Dusan Steinhauser}

\begin{abstract}
The competitiveness of a particular national economy and its business environment is critical for the country's economic, political and societal development. Competitiveness can be analyzed using a diapason of single- and multi-factor competitiveness indicators that contribute to quantification as well as and the analysis of internal and external competitiveness determinants. Suitable levels of competitiveness measurements and analyses, be they in terms of a company or a nation, are a matter of continuous debates. The authors of this paper have used econometric equations (models) in order to quantify and qualify the impact of the institutional environment, a factor represented both by the quality of governmental and regulatory measures as well as the corruption perception index. Institutional environment impact was measured in terms of export performance, as this metric represents one of the most important single-factor indicators of competitiveness. For the purposes of our research, the precise quantification of exogenous variables was not a necessity; rather we evaluated the assessment of strength and direction of relations between endogenous and exogenous variables. Our assumption was grounded in the notion that a higher quality of institutional environment is characterized by a higher level of competitiveness and lower transaction costs based on the belief that export performance is a reliable measure of competitiveness. Our research demonstrated, however, that the export performance is not a universal indicator of competitiveness, a finding that signals the need to apply other indicators, most notably, multi-factor ones.
\end{abstract}

Keywords: competitiveness, export performance, household consumption, government effectiveness, regression analysis

JEL Classification: F110, F14, F15

Received: April, 2019

1st Revision: January, 2020

Accepted: January, 2020

\section{INTRODUCTION}

In our quickly developing globalized reality, the competitiveness of a particular national economy and its business environment is a critical factor for the economic, political and societal development of a country as well as its for economic alliances. Competition is becoming ever tougher within the seemingly shrinking global market. New measures and regulations are being introduced at the multilateral and bilateral as well as macro- and micro-economic levels with the 
goal of achieving prosperity and the stability of a country or economic alliance(s). The growth of competitiveness represents one determinant of aggregate export growth. For this reason, amongst other, competitiveness has been emphasized in debates and in research during the past few decades. For the purpose of this research, the authors have used econometric equations (models) with the aim of quantifying and qualifying the impact of the institutional environment, a factor represented both by the quality of governmental and regulatory measures as well as the corruption perception index (CPI). Export performance was identified as one of the most important single-factor indicators of competitiveness.

\section{THEORETICAL BACKGROUND}

Čekmeová (2016) argues that the "National competitiveness can be understood as a country's capability to establish itself in foreign markets due to price or other factors, but also [in terms of] an economy that is capable of achieving a high level of real earnings, a low unemployment rate and long-term sustainable growth." Even though as an subject of economic research competitiveness has been the focus of several scientific and political texts, no one single generally accepted conception of this complex term has emerged. Bris states how "[achieving higher] competitiveness is therefore a way towards progress that does not result in winners and losers - when two countries compete, both are better off." (Bris, 2018) In their paper, Cellini \& Soci (2002) list many definitions of the term competitiveness, claiming the concept to be ambiguous. This being said, competitiveness cannot be easily measured and quantitatively evaluated. One accepted attempt at a precise definition comes from Balassa (Cellini \& Soci, 2002) "We can say that a country has become more or less competitive if, as a result of cost-and-price-developments of other factors, its ability to sell in foreign and domestic markets has improved or deteriorated." In this context, Nevima (2014) points to the fact that "competitiveness is a multilayered and thus ambiguous term." The concept can be assessed according to a myriad of single- and multi-factor competitiveness indicators that contribute to quantification as well as analyses of internal and external competitiveness determinants. Within the framework of a national economy, research results from these analyses are a valuable source to creators of national economic policy or action plans for national economic development. Some authors perceive national competitiveness as an overrated factor, i.e. Čekmeová (2016) claims that it has taken on the characteristics of a doctrine (Klvačová, 2008). Nevertheless, as practical experience shows, comparing and testing different levels of competitiveness is justified from a governmental point of view. The reasons for this lie in the fact that government policies can make either a positive or a negative impact on economic environment, therefore influencing the competitiveness of the economy. Here the interest to evaluate competitiveness is oriented towards several indicators that we differ as multifactor and single-factor competitiveness indicators. Multi-factor competitiveness indicators are deemed more general and complex, i.e. factors which can identify the level of competitiveness of a country's economy in the international context and assure a more detailed understanding of the country's competitiveness structure. In case of the single-factor competitiveness indicators, the focus is a narrower one oriented towards, for example, exports and imports, export performance and / or cost-and-price relations (Tab. 1, Balaž et al., 2017), by which transaction costs, as a measurement of quality of business environment, can be estimated (Okruhlica, 2013). We also 
assume that the higher the quality of the institutional environment, the higher the level of competitiveness and the lower the transaction costs.

Tab. 1 - Indicators of competitiveness. Source: Baláž et al. (2017)

\begin{tabular}{|l|l|}
\hline Multi-factor/criteria Indicators & Single-factor Indicators \\
\hline Competitiveness Index (GCI) & Export volume development \\
\hline World Competitiveness Index (WCI) & Export growth rate development \\
\hline Doing Business Index (DBI) & $\begin{array}{l}\text { Average aggregate exports } \\
\text { (exports commodity structure) }\end{array}$ \\
\hline Knowledge Economy Index (KEI) & $\begin{array}{l}\text { Average aggregate imports } \\
\text { (imports commodity structure) }\end{array}$ \\
\hline & Relative Balance of Trade \\
\hline & Export performance \\
\hline & Net export value development \\
\hline & Export per capita \\
\hline & Revealed Comparative Advantages (RCA) \\
\hline & Turnover Transactions TOT \\
\hline & Unit Labor Costs (ULC) \\
\hline & Real Effective Exchange Rate (REER) \\
\hline & \\
\hline
\end{tabular}

Bayer (2018) has put forth a historical, retrospective overview of competitiveness from several cited sources, starting with the oldest conceptions of the idea to those of current times. Competitiveness was and still is a primary focus in terms of several economic theories (e.g. mercantilism, classical economy, new trade economy) that offer a demarcating picture of the term competitiveness in the framework of economic theory. Mercantilism does not recognize the term competitiveness per se, however, the policy does deal with the wealth of a country and its ability to succeed internationally. The theoretical basis for competitiveness is rooted in mercantilist theory, a set of frameworks founded with emphasis on a country's wealth accumulation and its ability to establish itself in international trade. Differing from this theory is that of classical economy and its most notable representatives Smith and Ricardo, who concentrated on the field of production, the establishment of liberalism, market competitiveness and free trade. These theorists did not employ the term competitiveness, but rather referred to comparative advantages. As Bayer (2018) further states, more recently Ohlin \& Heckscher of the neoclassical school designed a simple model for evaluating international trade using the comparative advantages of economic subjects from different countries that are involved in production of diverse products. Historically speaking, competitiveness was firstly analyzed at the company level, i.e. a firm's capability to successfully compete with other companies in local as well as foreign markets. (Law, 2010; Bayer, 2018) In the early 80s, according to Botos (1982), a product competitiveness lies in the fact when price, quality and technical value of products of a company are lower than a price, quality and technical value of a product of another company (Bayer, 2018). Such understanding of the competitiveness, however, excluded the external environment, most notably world economy, that induces a fundamental impact on the company competitive conditions. Later on, 
therefore, the stronger globalization wave in the 1980s initiated focusing on national levels when competitiveness measurement is concerned. Porter (1990) has depicted the main determinants of competitiveness in the form of a diamond (firm strategy, structure and rivalry, factor conditions, related and supporting industries, demand conditions). He claims that on their level, companies reach advantages through innovation. Regarding the role of government in making and sustaining competitive advantage, the author points out the following two ideas. One group pursues the idea that the government must take the role of competitiveness maker. The other group advocates for governmental exclusion from the competitive advantages creating process. Porter perceives both of these paths as incorrect "Government's proper role is as a catalyst and challenger; it is to encourage - or even push - companies to raise their aspirations and move to higher levels of competitive performance...." Later on, his work evoked reactions of many economists, who have given both arguments pro and contra as well as those who strived to offer the improved versions of Porter's work. The greatest opponent of the national competitiveness concept is Krugman (1994) "Thinking and speaking in terms of competitiveness poses three real dangers. First, it could result in the wasteful spending of government money [...] Second, it could lead to protectionism and trade wars. Finally, and most important, it could result in bad public policy on a spectrum of important issues." Whether or not to deal with competitiveness at the company or country level is still a matter of many debates. "A mismatch between the corporate and national economic view of competitiveness stemmed from the fact that the company can be well-competitive not only via technological and product innovation, but also due to low labor costs, low input factors, savings in environmental costs, depreciated currency or price dumping at the expense of domestic customers, etc. These factors, however, appear to be counterproductive at the national economy level" (Kašt’áková \& Žatko, 2018).

A new institutional economic theory deals with quality of institutional environment through the level of transaction costs. According to Williamson (1990), transaction costs are related to imperfect information, risk of opportunism and asset particularities in economy. Asset particularity occurs if abandonment of contract between the contract parties could potentially imperil one or the other contract parties. Coase (1937) stipulated that there are costs that justify the existence of companies per se.“... the operation of a market costs something and by forming an organization and allowing some authority (an "entrepreneur") to direct the resources, certain marketing costs are saved. The entrepreneur has to carry out his function at less cost, taking into account the fact that he may get factors of production at a lower price than the market transactions which he supersedes, because it is always possible to revert to the open market if he fails to do this." It is difficult to quantify transaction costs, however, one of the ways that Okruhlica (2013) used is estimating the level of transaction costs via competitiveness indices. We suppose that the higher quality of institutional environment is characterized by higher competitiveness, lower level of transaction costs, therefore we test the export performance as a measure of competitiveness. Mlčoch (2005) claims that the new institutional economic theory was influenced by transformation process. Besides others, he argues about the experiences of the former socialistic countries where he identifies two directions of influence: the first one is strengthening of the state in the modern market economy and the second one is the importance of informal institutions. In general, institutions are divided into formal, with a legislative character, and informal, cultural institutions. Our long-term research focus is inspired mostly by the analysis of formal and infor- 
mal institutions that are a part of institutional environment as well as our eagerness to quantify transaction costs. Also, Bournakis \& Tsoukis (2013) attempt to uncover some of the institutional determinants of export performance. They confirm that structural competitiveness may also be important for export performance. We are also inclined to believe that freer institutional environment (without state interventions) acts as stimuli to business activity, therefore influencing economic performance and wealth of citizens. “... government spending becomes an unavoidable burden as growth in the size and scope of the public sector leads inevitably to misallocation of resources and loss of economic efficiency. Volumes of research have shown that excessive government spending that causes chronic budget deficits and the accumulation of public debt is one of the most serious drags on economic dynamism (The Heritage Foundation, 2018)."

\section{RESEARCH OBJECTIVE, METHODOLOGY AND DATA}

The influence of good quality institutional environment is recently given a great importance when export performance measurement is concerned. As above mentioned, the main objective of our research is to quantify and qualify the impact of institutional environment represented by indicators of government effectiveness, regulatory quality and corruption perception on export performance as one of the important single-factor indicators of competitiveness. The selected indicators of institutional environment presented in Table 2 enable us to characterise formal institutional environment (the Worldwide Governance Indicators government effectiveness and regulatory quality) as well as informal institutions (Transparency International, 2018).

We formulated the following hypotheses:

H1: Export performance of national economy will directly increase with increasing both the government effectiveness and regulatory quality.

H2: Export performance of national economy will directly increase with decreasing corruption perception.

For the purpose of our research, the precise quantification of exogenous variables is not a necessity. We rather take notice of the assessment of strength and direction of relations between endogenous and exogenous variables. We have used linear regression analysis, which enabled the analysis of relations between the chosen variables. The variable household consumption expenditure was added as a control variable because we assumed that the countries with a higher level of household consumption have a lower rate of exports, therefore achieving lower values of export performance. "The relationship between domestic demand and exports from a macroeconomic perspective builds on the seminal paper by Ball et al. (1966) for the case of the UK. This framework has found support in recent microeconomic theory and empirical evidence - see, for example, Vannoorenberghe (2012) for French firms and Altomonte et al. (2013) for a dataset covering four European countries: France, Germany, Italy and UK. A survey of the literature rationalising the negative effect of domestic demand on exports performance is presented in Esteves \& Rua (2013, 2015)." Aggregate consumption of a country is composed of both household consumption as well as government consumption. We have decided to include solely the household consumption since the government consumption decreased the testifying ability of the model. 
Therefore, we formulated the hypotheses H3: Export performance of national economy will directly increase with decreasing household consumption.

Besides these logical assumptions, our analysis was also influenced by our effort to design a simple linear regression analysis. In the statistical context, we have opted for the most effective version as well as layout of analysis, including the choice of variables. That way, we have gained a relatively simple and repetitive analysis of the examined relations. The econometric model is presented as follows (Lukáčik et al., 2011):

$y_{i}=\beta_{0}+\beta_{1} x_{i 1}+\beta_{2} x_{i 2}+\ldots+\beta_{k} x_{i k}+u_{i}$;

in which $y_{i}$ represents $i$ observations of endogenous variable, $x_{i j}$ represents exogenous variables. $\beta_{0}, \beta_{1}, \beta_{k}$ represent unknown estimated parameters and ui represents a random component, where we estimate that it equals 0 for cross-sectional data. We have designed this paired model of regression analysis by using economic software GRETL and descriptive statistics of the software Microsoft Excel. Both sides of econometric equation were presented as logarithms, therefore enabling us to interpret such adjusted analysis as an elasticity in percentage changes. Dependent and independent variables are depicted in Table 2. Columbia was disregarded in the course of observation due to its negative value of Gov_Eff_2014, therefore eliminating its logarithm presentation, whilst Switzerland is reported together with Lichtenstein in the UNCTAD database. Finally, we have made graphic testing of a relationship between export performance and household consumption in the software GRETL.

Tab. 2 - Dependent (DV) and independent (IV) variables. Source: own processing by UNCTAD (2018), Kaufmann \& Kraay (2018), WBG (2018), Transparency International (2018)

\begin{tabular}{|c|c|}
\hline Variable & Description \\
\hline EP_2016 (DV) & $\begin{array}{l}\text { Export performance from the year } 2016 \text { - "Exports of goods and } \\
\text { services as share on GDP - Exports of goods and services represent } \\
\text { the value of all goods and other market services provided to the rest } \\
\text { of the world. They include the value of merchandise, freight, insur- } \\
\text { ance, transport, travel, royalties, license fees, and other services, such } \\
\text { as communication, construction, financial, information, business, } \\
\text { personal, and government services. They exclude compensation of } \\
\text { employees and investment income (formerly called factor services) and } \\
\text { transfer payments (WBG, 2018)." }\end{array}$ \\
\hline $\begin{array}{l}\text { Household_con- } \\
\text { sumption } \\
\text { (HC)_2016 (IV) }\end{array}$ & Household consumption expenditure from the year 2016 in mill. USD \\
\hline CPI_2014 (IV) & $\begin{array}{l}\text { Transparency International corruption perception index from the year } \\
2014 \text { (0-100, higher value means a higher quality; values from interval). }\end{array}$ \\
\hline
\end{tabular}




\begin{tabular}{|l|l|}
\hline Gov_Eff_2014 (IV) & $\begin{array}{l}\text { Government Effectiveness from the year } 2014 \text { (weak minus 2.5 to 2.5 } \\
\text { strong) - "Reflects perceptions of the quality of public services, the } \\
\text { quality of the civil service and the degree of its independence from po- } \\
\text { litical pressures, the quality of policy formulation and implementation, } \\
\text { and the credibility of the government's commitment to such policies } \\
\text { (Kaufmann \& Kraay, 2018)." This indicator combines the views of a } \\
\text { large number of enterprises, citizen and expert survey respondents in } \\
\text { industrial and developing countries. }\end{array}$ \\
\hline Reg_Quality_2014 \\
(IV) & $\begin{array}{l}\text { Regulatory Quality from the year 2014 (weak minus 2.5 to 2.5 strong) } \\
\text { - "Reflects perceptions of the ability of the government to formulate } \\
\text { and implement sound policies and regulations that permit and pro- } \\
\text { mote private sector development (Kaufmann \& Kraay, 2018)." This } \\
\text { indicator combines the views of a large number of enterprises, citizen } \\
\text { and expert survey respondents in industrial and developing countries. }\end{array}$ \\
\hline
\end{tabular}

In order to achieve relevant results, we have used data of the OECD (2019) countries that are being considered as developed national economies and operating on the principles of democracy and market economy, thus representing a homogeneous group. The input data that are defined in Table 2 are depicted using descriptive statistics in Table 3.

Tab. 3 - Descriptive statistics. Source: own processing by UNCTAD (2018), Kaufmann \& Kraay (2018), WBG (2018), Transparency International (2018)

\begin{tabular}{|l|l|l|l|l|l|}
\hline & Mean & St. Dev. & Kurt. & Skew. & Count \\
\hline EP_2016 & 54.21 & 38.50 & 9.36 & 2.55 & 36 \\
\hline Household_consumption_2016 & $811,274.60$ & $2,159,591.91$ & 29.86 & 5.29 & 36 \\
\hline Gov_Eff_2014 & 1.30 & 0.51 & -0.64 & -0.50 & 36 \\
\hline Reg_Quality_2014 & 1.28 & 0.48 & -1.02 & -0.36 & 36 \\
\hline CPI_2014 & 68.53 & 15.38 & -0.86 & -0.37 & 36 \\
\hline
\end{tabular}

Descriptive statistics and regression analysis in Table 3 were made and interpreted in accordance with expertise resources (Pacáková et al., 2009; Lukáčik et al., 2011). The average value of export performance in the year 2016 represents 54.22 export's share on GDP whilst household consumption in the OECD (2019) countries amounts the value of mill. 811,275 USD. Kurtosis values are rather interesting, especially in the case of household consumption where the split file is significantly sharper than the regular split. When statistical files are observed, the USA or Luxembourg represent those examples. The negative rate of narrowness means a left-sided division of countries, stating that the file encompasses a larger number of countries with a higher value than average. The positive rate of narrowness indicates vice-versa. 


\section{RESULTS AND DISCUSSION}

In our research, where export performance was understood as an indicator of competitiveness, we have tested the assumption that this indicator is influenced by the quality of government and regulatory measures as well as CPI. Table 4 includes multiregression linear analysis in a logarithm form. Based on statistical tests, this analysis is generally significant (without Ramsey RESET test for specification and Centered R-squared. There are variables that explain the dependent variable more fundamentally. On the other hand, we have adopted the model specification because it is difficult to find sensitive variables affecting export performance that has its specificities, e.g. consumption and economy size). Variables CPI and household consumption were estimated with the highest statistical significance and with the correct signs. Other variables were estimated with statistical insignificance or, in the case of government effectiveness, the regression coefficient had incorrect and negative sign.

Tab. 4 - Regression analysis, method OLS, dependent variable: 1_EP_2016 (N=36). Source: own processing by UNCTAD (2018), Kaufmann \& Kraay (2018), WBG (2018), Transparency International (2018)

\begin{tabular}{|l|l|l|l|l|l|}
\hline & Coefficient & Std. Error & t-ratio & p-value & \\
\hline 1_Household_consumption_2016 & -0.233587 & 0.0515770 & -4.529 & $<0.0001$ & $* * *$ \\
\hline 1_Gov_Eff_2014 & -0.618831 & 0.321822 & -1.923 & 0.0634 & $*$ \\
\hline 1_Reg_Quality_2014 & 0.0542096 & 0.385483 & 0.1406 & 0.8890 & \\
\hline 1_CPI_2014 & 1.60780 & 0.154836 & 10.38 & $<0.0001$ & $* * *$ \\
\hline Uncentered R-squared & 0.985130 & & & & \\
\hline Centered R-squared & 0.371415 & & & & \\
\hline P-value(F) & $9.58 \mathrm{e}-29$ & & & & \\
\hline F(4.32) & 530.0045 & & & & \\
\hline
\end{tabular}

White's test for heteroscedasticity $\mathrm{P}($ Chi-square $(14)>$ LM 16.6469) $=0.275483$

Test for normality of residual - Test stat.: Chi-square $(2)=0.711358(\mathrm{p}$-value $=0.700697)$

Ramsey RESET test $\mathrm{P}(\mathrm{F}(2.30)>4.92194)=0.0141708$

For our purposes it is interesting to picture the model in a graphic manner and follow the placement of countries under observation. Nevertheless, a decreased value of the Centered R-squared indicates worsen statistical strength of the model although it did enable us to identify those countries, for which the value of export performance is not significant in such a degree. Those groups of countries can be observed in Figure 1. 


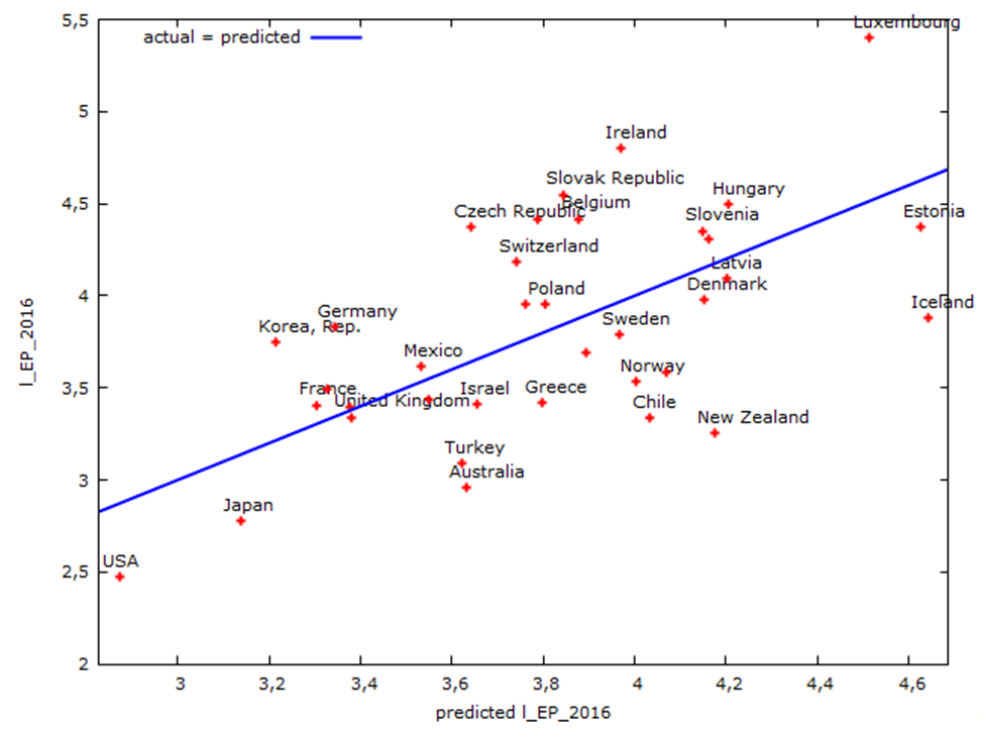

Fig. 1 - Figure of actual and predicted values of a dependent variable (EP_2016). Source: own processing by UNCTAD (2018), WBG (2018)

As evidenced by Figure 1, export performance is a suitable indicator of competitiveness only for a specific group of the OECD (2019) countries. It points out that it is not necessarily a good indicator of competitiveness for the economies with a high level of household consumption, i.e. it is significantly influenced by the size of national economies. It is possible to rather precisely identify two groups of countries: one with a low level of internal consumption, but with a high level of export performance (countries high above the curve), mostly encompassing small economies whose economic growth is strongly dependent on export performance such as Luxembourg, Ireland, the Slovak Republic, the Netherlands, Switzerland, i.e. the other group being represented by, e.g. USA, Japan, Australia (countries high under the curve) having a high level of household consumption and a relatively low level of export performance, i.e. their economic growth is not primarily dependent on export performance.

As already mentioned, we assume a strong dependence between export performance values and household expenditures. Therefore, we have correspondingly designed a graphic form of the regression analysis with an aim of reviewing this particular relationship between export performance and household consumption (Figure 2). 


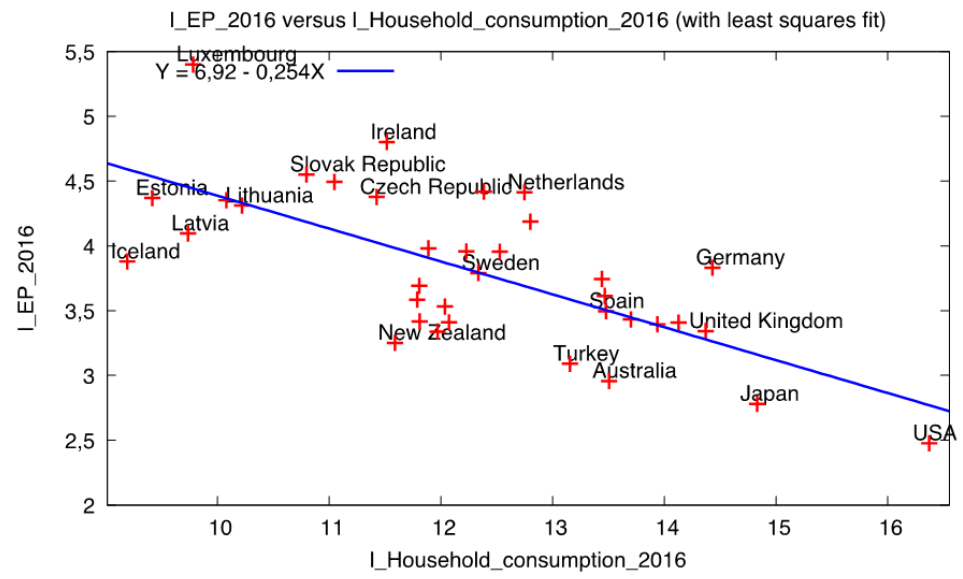

Fig. 2 - Scatterplot between Export performance and Household consumption. Source: own processing by UNCTAD (2018), Kaufmann \& Kraay (2018), WBG (2018), Transparency International (2018)

In our research, we have dealt with the OECD (2019) countries, that share a relatively high level of economic development and democracy whilst respecting the principles of market economy, which were initially identified as a rather homogeneous group. Nevertheless, its heterogeneity lies in the fact that there are vast differences regarding their economic strength and size (e.g. USA, Luxembourg, the Czech Republic, Singapore, Japan, Australia, etc.).

\section{The outcomes of our research are as follows:}

Firstly, we have tested the two hypotheses (H1 and $\mathrm{H} 2$ ) on export performance responsiveness to the chosen factors from institutiona environment (government effectiveness, regulatory quality and CPI). We did not confirm the hypothesis $\mathrm{H} 1$ as for the influence of both the government effectiveness and regulatory quality on export performance. Even more regulatory quality is a statistically insignificant variable whilst government effectiveness was estimated with the incorrect sign, meaning that we could have eliminated these variables from our research. We did not confirm the hypothesis $\mathrm{H} 2$, asserting the growth of export performance with a decrease in corruption perception. On the one hand, we found out that when the informal institution of corruption increases by $1 \%$, we expect the increase of export performance by $1.61 \%$, however, following to this model specification only. If we leave the constant in the model, only the constant itself and the Household_consumption_2016 variable remain statistically significant (estimated parameter of -0.25). Since we have removed the constant in the model, in the next step, we wanted to prove the credibility of the estimate of the CPI variable. For this purpose, we used pairwise regression analysis. We used it to find out the significance of the converted CPI and its impact on export performance. The pairwise regression analysis between CPI and export performance in a logarithmic form did not show statistical linkage between variables. It even revealed too large residues in individual observations (for example, Luxembourg, res. 1.59; USA, res. -1.33; Japan, res. -1.03; Slovak Republic, res. 0.75; Czech Republic, res. 0.57). We can consider the perceived corruption (CPI) as a proxy variable for the quality of the institutional system, like authors Evan \& Bolotov (2014) when studying the relationtiship between corruption (based on data from the 
Transparency International, the Worldwide Governance Indicators, and the Heritage Foundation) and foreign direct investments: "In this paper, we attempted to present a theoretical explanation and econometric verification of the weak relation between corruption (as a representation of the political environment) and FDI inflows in countries." To summarize, our results again confirm the fact that export performance is not a suitable indicator (as a single measurement) for measuring competitiveness.

Finally, we confirmed hypothesis $\mathrm{H} 3$. With the $1 \%$ increase of the household consumption expenditures we expected the values of export performance to decrease by $0.23 \%$. National economies experiencing growth mostly due to household consumption are not primarily dependent on international trade, therefore, their export performance is lower. We observe that those countries are further away from the curve, generally falling under it, as shown in Figure h 1 . However, even such countries can be divided into two categories, with the first being one that of large and economically developed countries which maintain a high volume of mostly sophisticated exports, though their exports ratio in the structure of GDP is relatively low, e.g. USA, Australia, New Zealand, Japan. The other category encompasses those countries whose national economy structure is mostly oriented towards domestic demand, and their exports ratio in the structure of GDP is not significant in such a degree, e.g. Turkey, Greece, Chile, Iceland, Finland, Norway. Those economies that are high above the curve are, by contrast, the countries that have shown their export performance to be above average in terms of the researched variables. These represent developed economies such as Luxembourg, Ireland, the Slovak Republic, the Netherlands, Switzerland, the Czech Republic and South Korea, nations with a relatively small internal market, therefore, growth is mostly induced by exports. A specific case is represented by Germany, which is positioned rather high above the curve, proving that even with its large domestic market, a country can still be highly export-oriented. Countries in the proximity of the curve can be labelled "statistically average" in the context of our model.

The regression analysis results, presented in Table 4 as well as in Figure 2, confirm our assumption of a high dependence between household consumption and export performance.

Our research complements extant literature investigating the impact of institutional environment on export. Jong \& Bogmans (2011) focused on trade-related corruption, which in general hampers international trade: "The results are most robust for the index derived from the WBES [World Business Environment Survey] and for corruption in the exporting country. Quite different results are obtained when we use indicators of corruption and quality of institutions directly related to international trade." Faruq (2011) examined the relationship between a country's institutional environment and the quality of its exports. He argues that "institutional factors such as widespread corruption, inefficient bureaucracy, and high risk of expropriation of private property by government can create uncertainty among producers and discourage them from investing and innovating over the long term. This can limit the ability of producers to improve the quality of their exports in the future." According to his findings, corruption appears to be most robustly associated with export quality.

Our study also contributes to the literature on the determinants of export performance, which has been synthesized and evaluated by the authors Chen et al. (2016), who concluded that: "Research into export performance is still limited." 
In this study, we have furthermore confirmed the negative effect of domestic demand (household consumption being a component of it) on exports performance presented by Esteves \& Rua (2013, 2015). Moreover, we have quantified this dependency for the OECD (2019) countries. According to our findings, the proportionality of a negative effect of household consumption on export performance is low.

Finally, we propose to explain competitiveness not only in terms of export performance dependence, but also in terms of productivity. M. E. Porter stated: “A nation's standard of living depends on the capacity of its companies to achieve high levels of productivity - to increase productivity over time. Sustained productivity growth requires that an economy continually upgrades itself." (Porter, 1990) P. Krugman differentiates between competitiveness and productivity: "In other words, for an economy with very little international trade, 'competitiveness' would turn out to be a funny way of saying 'productivity' and would have nothing to do with international competition” (Krugman, 1994).

\section{CONCLUSION}

In evaluating competitiveness of national economies, the various theories and points of view are frequently debated. It is necessary to understand competitiveness as a complex phenomenon that includes macro- and micro-economic fields also strongly influenced by further factors that exist in between these two economic categories. The new and often harsh conditions characteristic of globalized economic competition force us to recognize the term competitiveness as a wide spectral topic that can be measured and analyzed via numerous indicators, both individually as well as in their complexity.

The main objective of our research was to quantify and qualify the impact of institutional environment, represented by indicators of government effectiveness, regulatory quality and corruption perception. The institutional impact on export performance was identified as one of the important single-factor indicators of competitiveness.

Export performance may be perceived as one of the fundamental competitiveness indicators for a particular group of countries only. This group is typically represented by developed yet small economies whose economic growth is primarily determined by exports (e.g. Luxembourg, Ireland, the Netherlands, countries of Visegrad Group, etc.). The risk that comes from such a level of dependency, which cannot be avoided in the globalized world, is their substantial dependency on external environment, mostly concerning the conjuncture cycles that emerge with the functioning of the world economy. In this context, successful adaptation becomes possible when suitable economic and political policies and strategies are applied to the inherited and gained comparative advantages concurrently supported within a solid institutional environment, i.e. benefits in terms of qualitative and legislative factors based on the principles of transparency, democracy and the elimination of opportunism, i.e. the elimination of the promotion of exclusive self-interest even if it is not an indication of unethical and illegal behavior. The influence of institutions on competitiveness was not confirmed by our study, a result which we attribute to the specific features of the model. Notwithstanding our present findings, we continue to perceive both formal and informal institutions as important factors in reaching competitiveness, a position which has also been maintained by renowned world institutions (GCI, WCI, and BD) 
which measure competitiveness via multi-factor indices whilst also including institutions in their evaluations.

We have confirmed a significant influence of the chosen variable household consumption on export performance in the sense that the higher the household consumption, the lower the export performance. Our research outcomes also indicate that when the influence of household consumption on export performance of the OECD (2019) countries is observed, it is necessary to differentiate between several groups of countries.

Firstly, countries with a low household consumption and a high level of export performance (Luxembourg, Ireland, the Slovak Republic, the Netherlands), in which the level of export performance reached was higher than predicted.

Secondly, countries with a higher household consumption (when compared to the first group) and a lower level of export performance than assumed due to support of growth by domestic consumption. This group can be further differentiated according to countries with highly sophisticated exports (e. g. USA, Japan, Australia) and countries with less sophisticated exports (e. g. Turkey, Greece, Chile). In our opinion, this differentiation in our model was determined mostly by the varying levels of CPI.

Germany represented a specific case, i.e. it reached a rather high level of export performance whilst parallelly maintaining high household consumption. One possible reason is the uniqueness of Germany's national economy, which encompasses a huge production potential of highly sophisticated products that can compete in the world market. For this reason, economic growth is not only determined by high household consumption but also by high export performance.

Finally, the economies we refer to as "statistically average" according to our model specification (e.g. Mexico, Austria, Denmark, UK), with the above mentioned relation applicable in this context.

Our study contributes to rather limited literature regarding the determinants of export performance. Furthermore, it complements the literature on household consumption impact on export performance by quantifying the proportionality of this effect. We conclude that export performance is not a universal indicator of competitiveness, therefore, it is advisable that other indicators of competitiveness, mostly multi-factor ones, are used when evaluating competitiveness.

One limitation of our research is that it covers the OECD (2019) countries only. For other countries (developing or emerging economies), the relationships presented by this research should be demonstrated in other studies. Moreover, this research takes into account only selected factors that may influence export performance, while other factors of export performance may prove relevant for the countries not included. From a statistical point of view, omitting a constant from the regression equation is a major limitation, but one that was warranted because of the higher statistical significance of the independent variables. We partially offset this limitation with the pairwise regression analysis between the dependent variable and CPI (since this was estimated with up to $99 \%$ probability in the model with the omitted constant).

Even though we were not able to confirm the impact of institutional environment on export performance, this does not necessarily indicate that institutional environment does not influence competitiveness. We merely provide evidence that export performance as a single-factor indicator has a limited capacity to indicate competitiveness. We believe that especially for developed 
economies, the quality of the institutional environment represents one of the crucial determinants of competitiveness, therefore we strongly suggest further research in this field.

\section{Acknowledgement:}

This paper is a part of a research project of the Ministry of Education, Family and Sports of the Slovak Republic VEGA (in the period 2020 - 2022) No. 1/0777/20: The Belt and Road initiative - an opportunity or a threat for the EU and Slovak export competitiveness?

\section{References}

1. Altomonte, C., Sono, T., \& Vandenbussche, H. (2013). Firm-level productivity and exporting: diagnosing the role of financial constraints", chapter 2 in Product Market Review 2013, EU publication. In ECB (2016). On domestic demand and export performance in the euro area countries: does export concentration matter? Working Paper Series. Retrieved January 29, 2020 from https://www.ecb.europa.eu/pub/pdf/scpwps/ ecbwp1909.en.pdf

2. Baláž, P., Hamara, A., \& Sopková, G. (2017). Konkurencieschopnost’ a jej význam v národnej ekonomike: (zmeny a výzvy v obdobi globálnej finančnej krízy) (2. vyd). Bratislava: Sprint 2.

3. Ball, R. J., Eaton, J. R., \& Steuer, M. D. (1966). The Relationship Between United Kingdom Export Performance in Manufactures and the Internal Pressure of Demand. The Economic Journal, 76 (303). https://doi.org/10.2307/2229518. In ECB (2016). On domestic demand and export performance in the euro area countries: does export concentration matter? Working Paper Series. Retrieved January 29, 2020 from https://www.ecb.europa.eu/pub/ pdf/scpwps/ecbwp1909.en.pdf

4. Bayer, J. (2018). Vplyv energetickej politiky na konkurencieschopnost’ Európskej únie v postkrízovom období: dissertation. Bratislava.

5. Botos, J. (1982). International Competitiveness and Price Revolution. Budapest 1982. Kozgazdasagi es Jpgi Konyvkiado. In Bayer, J. (2018) Vplyv energetickej politiky na konkurencieschopnost' Európskej únie v postkrízovom období: dissertation. Bratislava.

6. Bournakis I., \& Tsoukis Ch. (2013), Government Size, Institutions, and Export Performance among OECD Economies, Middlesex University, Working Paper, draft version. In Bierut, B., \& Kuziemska-Pawlak, K. (2016). Competitiveness nad Export Performance of CEE Countries. Eastern European Economics, 55 (6), 522-542.

7. Bris, A. (2018). IMD World Competitiveness Center. Retrieved February 4, 2019, from https://www.imd.org/wcc/world-competitiveness-center/

8. Cellini, R., \& Soci, A. (2002). Pop competitiveness. PSL Quarterly Review, 55 (220). Retrieved February 4, 2019, from https://ojs.uniroma1.it/index.php/PSLQuarterlyReview/ article/view/9905/9787

9. Coase, R. H. (1937). The Nature of the Firm. Economica, 4 (16), 386-405. http:// doi/10.1111/j.1468-0335.1937.tb00002.x

10. Čekmeová, P. (2016). Konkurencieschopnost' ako ciel’ hospodárskej politiky. Politická Ekonomie: Teorie, Modelováni, Aplikace, 64 (3), 338-350. https://doi.org/10.18267/j.polek.1074

11. Esteves, P. S. \& Rua, A. (2013). Is there a role for domestic demand pressure on export performance? ECB Working Paper no 1594, European Central Bank. In ECB (2016). 
On domestic demand and export performance in the euro area countries: does export concentration matter? Working Paper Series. Retrieved January 29, 2020 from https:// www.ecb.europa.eu/pub/pdf/scpwps/ecbwp1909.en.pdf

12. Esteves, P. S. \& Rua, A. (2015). Is there a role for domestic demand pressure on export performance? Empirical Economics, 49 (4), 1173-1189. In ECB (2016). On domestic demand and export performance in the euro area countries: does export concentration matter? Working Paper Series. Retrieved January 29, 2020 from https://www.ecb.europa. eu/pub/pdf/scpwps/ecbwp1909.en.pdf

13. Evan, T., \& Bolotov, I. (2014). The Weak Relation between Foreign Direct Investment and Corruption: A Theoretical and Econometric Study. Prague Economic Papers, 23 (4), 474-492. https://doi.org/10.18267/j.pep.494

14. Faruq, H.A. (2011). How institutions affect export quality. Economic Systems, 35 (4), 586-606. https://doi.org/10.1016/j.ecosys.2011.05.001

15. Chen, J.K., Sousa, C.M.P., \& He, X.M. (2016). The determinants of export performance: a review of the literature 2006-2014. International Marketing Review, 33 (5), 626-670.

16. Jong, E., \& Bogmans, C. (2011). Does corruption discourage international trade? European Journal of Political Economy, 27 (2), 385-398. https://doi.org/10.1016/j.ejpoleco.2010.11.005

17. Kašt’’áková, E., \& Žatko, M. (2018). Vplyv geopolitických ₹mien na potenciál rabraničnoobchodných vžtahov Slovenska s Ruskom. Bratislava: EKONÓM.

18. Kaufmann, D., \& Kraay, A. (2018). World Governance Indicators. Retrieved July, 16, 2018 from http://info.worldbank.org/governance/wgi/index.aspx\#home

19. Klvačová, E. (2008). Doktrína konkurenceschopnosti národních státu a nekterá její úskalí. Domnělé a skutečné bariéry konkurenceschopnosti EU a ČR. Praha: Vzdelávací stredisko na podporu demokracie. In Čekmeová, P. (2016). Konkurencieschopnost' ako ciel' hospodárskej politiky. Politická Ekonomie: Teorie, Modelování, Aplikace, 64 (3), 338-350. https://doi.org/10.18267/j.polek.1074

20. Krugman, P. (1994). Competitiveness: A Dangerous Obsession. Foreign Affairs. 73 (2), 28 44. Retrieved February, 4, 2019 from https://www.foreignaffairs.com/articles/1994-03-01/ competitiveness-dngerous-obsession

21. Law, J. (2010). Dictionary of Business and Management. New York: Oxford University Press. In Bayer, J. (2018) Vplyv energetickej politiky na konkurencieschopnost’ Európskej únie v postkrízovom období: dissertation. Bratislava.

22. Lukáčik, M., Lukáčiková, A., \& Szomolányi, K. (2011). Ekonometrické modelovanie v programoch EViews a Gretl. Bratislava: EKONÓM.

23. Mlčoch, L. (2005). Instituci onální ekonomie. Praha: Univerzita Karlova v Praze. Nakladatelství Karolinum.

24. Nevima, J. (2014). Konkurenceschopnost regionu Visegrádské ctyrkey (Teoretické a empirické prístupy k. vymežení, mèrení a hodnocení). Praha: Professional Publishing.

25. OECD (2019). Membership and partners. Retrieved February, 2019 from http://www.oecd. org/about/membersandpartners/ 
26. Okruhlica, F. (2013). Výška transakčných nákladov ako meradlo kvality podnikatel’ského prostredia v Slovenskej republike a v Českej republike. Aktuálne Problémy Podnikovej Sféry 2013: [Recenzovaný] Zborník Vedeckých Prác, 434-439.

27. Pacáková, V., Labudová, V., Sipková, L., Šoltés, E., \& Vojtková, M. (2009). Štatistické metódy pre ekonómov. Bratislava: Iura Edition.

28. Porter, M., E. (1990). The competitive advantages of nations. Harvard Business Review, 73- 91. Retrieved February 4, 2019 from http://www.economie.ens.fr/IMG/pdf/ porter_1990_-_the_competitive_advantage_of_nations.pdf

29. The Heritage Foundation. (2018). Methodology. Retrieved January 21, 2019 from https:// www.heritage.org/index/book/methodology\#government-size

30. Transparency International. (2018). CPI 2014. Retrieved November 10, 2018 from https:// www.transparency.org/cpi2014/results

31. UNCTAD. (2018). UNCTADStat - Gross domestic product: GDP by type of expenditure, VA by kind of economic activity, total and shares, annual. Retrieved November 13, 2018 from http://unctadstat.unctad.org/wds/TableViewer/tableView.aspx

32. Vannoorenberghe, G. (2012). Firm-level volatility and exports. Journal Of International Economics, 8 (1), 57-67. https://doi.org/10.1016/j.jinteco.2011.08.013 In ECB (2016). On domestic demand and export performance in the euro area countries: does export concentration matter? Working Paper Series. Retrieved January 29, 2020 from https:// www.ecb.europa.eu/pub/pdf/scpwps/ecbwp1909.en.pdf

33. WBG. (2018). World Development Indicators - Exports of goods and services (\% of GDP) Update January, 30, 2019. Retrieved February 28, 2019 from http://api.worldbank.org/v2/ en/indicator/NE.EXP.GNFS.ZS?downloadformat=excel

34. Williamson, O. E. (1990). Die ökonomischen Institutionen des Kapitalismus: Unternehmen, Märkte, Kooperationen. Tübingen: Mohr.

\section{Contact information}

doc. Ing. Viera Ruzekova, PhD.

University of Economics in Bratislava

Faculty of Commerce

Department of International Trade

Slovakia

E-mail:viera.ruzekova@euba.sk

doc. Ing. Zuzana Kittova, PhD., MBL-HSG

University of Economics in Bratislava

Faculty of Commerce

Department of International Trade

Slovakia

E-mail: zurana.kittova@euba.sk

ORCID: 0000-0002-8903-4033
Ing. Dusan Steinhauser, PhD.

University of Economics in Bratislava

Faculty of Commerce

Department of International Trade

Slovakia

E-mail:dusan.steinhauser@euba.sk

ORCID: 0000-0003-0708-9020 